\title{
An evaluation of the California Instructional School Garden Program
}

\author{
Eric L Hazzard', Elizabeth Moreno², Deborah L Beall ${ }^{2}$ and Sheri Zidenberg-Cherr ${ }^{1, *}$ \\ 'Department of Nutrition, University of California, Davis, One Shields Avenue, Davis, CA 95616, USA: \\ ${ }^{2}$ Nutrition Services Division, California Department of Education, Sacramento, CA, USA
}

Submitted 8 October 2010: Accepted 28 April 2011: First published online 2 August 2011

\begin{abstract}
Objective: California Assembly Bill 1535 awarded \$US 15 million to California public schools to promote, develop and sustain instructional school gardens through the California Instructional School Garden Program (CISGP). The present study was designed to assess the effectiveness of the CISGP at assisting schools in implementing, maintaining and sustaining an academic school garden programme, determine how schools utilized the funding they received and assess the impact of the California state budget crisis on the CISGP.

Design: A mid-term evaluation was used to assess the degree to which schools achieved their instructional garden-related goals.

Setting: California.

Subjects: Only schools that applied for the CIGSP grant as part of a school district and also provided a contact email and had a unique contact person were included in the study ( $n 3103,80 \cdot 6 \%$ ).

Results: In general, many schools reported not achieving their predicted goals with regard to the CISGP grant. Only $39 \cdot 4 \%$ of schools reported accomplishing all of their garden-related goals. Over one-third $(37 \cdot 8 \%)$ of schools reported that their school gardens were negatively affected by the California budget deficit. Conclusions: The difference between predicted and actual utilization of the CISGP grants may be due to a combination of the effects of budget shortfall and insufficiency of the grant award amount.
\end{abstract}

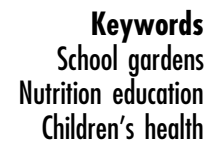

Keywords

Nutrition education

Children's health
Gardens in communities and on school grounds have made a tremendous resurgence over the past decade ${ }^{(1)}$. The practice of students participating in the gardening experience at school is not new; in fact, school gardens were introduced in the USA in the early $1900 \mathrm{~s}^{(2)}$. By 1918 every state in the USA had at least one school garden and contributed to the production of food during the war effort. More recently, and concomitant with a powerful environmental movement and an appreciation of the concept of integrated learning, the notion of school gardens as a learning tool has taken hold and school gardens are gaining popularity throughout the USA and other parts of the globe ${ }^{(3-5)}$.

In 1995, under the direction of the then State Superintendent of Public Instruction, Delaine Eastin, the California Department of Education (CDE) launched 'A Garden in Every School' Initiative ${ }^{(6)}$. This initiative encouraged schools to establish and sustain school gardens as a learning laboratory or outdoor classroom. The initiative was followed by the enactment of several Senate and Assembly bills (AB) for the implementation and sustainment of instructional school gardens; AB 1014, Instructional School Gardens
(1999), formally established the Instructional School Garden Program in California. The impetus for the Governor's and Legislature's decision to promote instructional gardens stemmed from the body of research demonstrating the potential of garden-based learning for enhancing academic achievement and promoting school environments as a way of improving the health and well-being of individual students in multiple facets of healthy youth development ${ }^{(1,2,4)}$.

In addition to the impact on academic achievement, the CDE also acknowledged that gardens could provide opportunities for children to improve their dietary behaviours. This is of utmost importance since the rates of obesity among children in the nation are reaching epidemic proportions $^{(7)}$. Several nutrition experts have promoted the concept that schools can utilize gardens as a tool to promote healthy eating habits ${ }^{(8)}$. Indeed, there have been studies demonstrating that children participating in school gardening activities have improved preferences for and intakes of vegetables ${ }^{(9-13)}$. On the basis of the evidence that school gardens can play an important role in creating a healthier and academically improved school environment ${ }^{(14)}, \mathrm{AB}$ 1535, California Instructional School Garden Program 
(CISGP), was enacted in 2006 and authorized the CDE to award \$US 15 million for grants to promote, develop and sustain instructional school gardens. In California, a school garden has been defined as 'plants grown in the ground, in raised beds, in pots or in greenhouses in both classrooms or outdoors $^{(15)}$.

The CISGP applications were available from February 2007 to April 2007. All public schools were eligible for the grant: \$US 5000 for schools with 1000 or more students and \$US 2500 for schools with fewer than 1000 students. The grant funds could be used for equipment, supplies and professional development but not for stipends for garden coordinators. All schools applied through their district office or county office of education. If they were a direct-funded Charter school, they could apply on their own behalf. Almost $40 \%$ of all California schools applied ( $n$ 3849, 39.5\%) and \$US $10 \cdot 9$ million was awarded. The majority of schools $(88.9 \%)$ applied as part of a school district. The grant funds were dispersed in January 2008.

The present study was designed to evaluate the effectiveness of the CISGP at assisting schools in implementing, maintaining and sustaining an academic school garden programme, determine how schools utilized the funding received and assess the impact of the California state budget crisis on the CISGP.

\section{Experimental methods}

\section{Study design}

A combination of formative and summative evaluation was used to determine the implementation and outcomes of the CISGP. A quasi-experimental pre/post-design was used to measure how schools implemented their programme and to evaluate each school's instructional gardenrelated goals by comparing what each school was able to accomplish with what they initially planned. The main outcome was utilization of the instructional garden for academic purpose. Only schools that applied for the CIGSP grant as part of a school district (88.9\%) were evaluated. The application period for the CISGP grants was February 2007 to April 2007. This was a non-competitive grant, meaning that all applicants that completed the School Site Information Form, hereafter referred to as the Garden Grant Pre-Survey (GGPS), were properly awarded funds from the CISGP. The mid-term survey was sent 14 months after the release of grant funds. The present study was approved by the Institutional Review Board of the University of California, Davis (UC Davis), with exempt status.

\section{Survey development}

All baseline information was collected from the GGPS, created by the CDE in collaboration with the Center for Nutrition in Schools, Department of Nutrition at UC Davis $^{(16)}$. The GGPS required each school site to answer eight questions. These questions assessed how the schools planned on utilizing funds, when the garden would be used, what subject areas would be taught using the garden, how many students would use the garden and what would be grown in the garden. The GGPS also contained a narrative section that allowed schools to briefly describe the projected use of funds.

The Garden Grant Follow-Up Survey (GGFS), a postimplementation survey, was developed to gather information about the schools' accomplishments and assess the impact of the California budget deficit on instructional school garden programmes. The questions in the present survey were identical to those of the GGPS, with the addition of questions pertaining to the impact of the budget deficit on the programme. SurveyMonkey was used to create and disseminate the GGFS.

\section{Survey distribution}

To be included in the evaluation, the school site had to be part of a school district, had to provide a contact email and had to have a unique contact person; 3103 of the possible 3849 schools met these criteria. The GGFS was sent out in March 2009 after removing blocked and incorrect email addresses. A total of 1992 surveys were sent and 861 responded, resulting in a response rate of $43 \cdot 2 \%$. Because of a lack of identification for 112 participants, only 749 schools could be matched to their GGPS when comparing corresponding answers (37.6\% response rate).

A modified Dillman's Tailored Design survey methodology was used to distribute the GGFS surveys through email: an initial pre-notice email was sent alerting school contacts about the upcoming survey and three additional emails containing survey links were sent over the next 3 weeks $^{(17)}$. A final email was sent containing a link to the survey that allowed for a higher response rate.

\section{Data transformation}

The last question on the GGPS asked applicants to briefly describe the projected use of funds for their school. A random sample of forty narratives was taken and these narratives were analysed using constant comparative analysis, after which three new categories were created on the basis of common themes. The remaining narratives were classified into these categories and the three categories were used as the basis for the question on the GGFS aimed at capturing additional uses of grant funds.

\section{Statistical analysis}

Descriptive statistics were used to report frequency data from both the GGPS and the GGFS. McNemar's $\chi^{2}$ test was used to compare dependent proportions between the GGPS and the GGFS. A $P$ value $\leq 0 \cdot 05$ was considered significant. The Statistical Package for the Social Sciences statistical software package version $17 \cdot 0$ (SPSS Inc., Chicago, IL, USA) was used to analyse data. 


\section{Results}

\section{Utilization of funds: comparison between} predicted and actual accomplishments

Although almost one-half of the schools (46.5\%) predicted that the grant would support the development of a new garden, only $35.3 \%$ reported that it did $(P<0 \cdot 001)$. Over half of the schools $(52 \cdot 9 \%)$ predicted that the grant would support the sustained use of an existing garden; however, only $45.0 \%$ reported that it $\operatorname{did}(P<0 \cdot 001)$. Over $40 \%$ of schools $(43 \cdot 1 \%)$ predicted that the grant would support the expansion of an existing garden, but only $37 \cdot 5 \%$ reported that it $\operatorname{did}(P=0 \cdot 01)$. Almost one-quarter of schools $(23 \cdot 0 \%)$ predicted that the grant would support the revitalization of a garden not currently in use and $22.6 \%$ reported that it $\operatorname{did}(P=0.886)$. In addition, $2 \cdot 3 \%$ of schools said that the grant did not support anything since they did not have a school garden (Table 1).

Almost all schools (96.0\%) planned on using the school garden during academic class time, but only $79 \cdot 2 \%$ did so $(P<0 \cdot 001)$. In addition, significantly fewer schools reported using the garden for instruction during lunch/recess time, or after school hours or before school hours $(P<0 \cdot 001$; Table 1$)$. For almost all subject areas, significantly fewer schools than planned used the garden to teach academic subjects $(P<0 \cdot 003)$. Agricultural studies was the only subject area that was taught using the school garden as much as predicted $(P=0 \cdot 065$; Table 1$)$.

\section{Additional utilization of funds}

Data from the GGFS indicated that the funds from the CISGP supported the School Wellness Policy (30.4\%), teaching California State Content Standards (63.5\%), garden activities, clubs or fund-raising activities (88.9\%; data not shown). Almost two-thirds of schools (63.5\%) reported that they were able to utilize all of their grant funds. Some schools (19.3\%) received all of their funds, but had not utilized all of their grant funds at the time of the survey. Other schools $(5 \cdot 3 \%)$ did not have all of their funds distributed to them, whereas others $(3 \cdot 2 \%)$ did not have any of their funds distributed to them (Table 2).

Less than $40 \%$ of schools $(39 \cdot 4 \%)$ reported that they were able to accomplish all their goals for their garden with the funds they received. Approximately one-quarter of schools $(25.9 \%)$ reported that the funds they received were not sufficient to reach their gardening goals, and $15 \cdot 6 \%$ of schools that reported that the funds they received were not sufficient to reach their gardening goals acquired other sources of funding (Table 2).

\section{Impact of the California budget crisis}

Approximately half of the schools $(50 \cdot 4 \%)$ reported that their school garden was not affected by the budget crisis.

Table 1 Evaluation of schools' goals

\begin{tabular}{|c|c|c|c|c|}
\hline & \multicolumn{2}{|c|}{ Response (before)t } & \multicolumn{2}{|c|}{ Response (after)‡ } \\
\hline & $\%$ & $n$ & $\%$ & $n$ \\
\hline \multicolumn{5}{|l|}{ What will the grant support? } \\
\hline Development of a new garden & $46 \cdot 5$ & 348 & $35 \cdot 1$ & $263^{\star \star \star}$ \\
\hline Sustained use of an existing garden & $52 \cdot 9$ & 396 & $45 \cdot 0$ & $337^{\star * *}$ \\
\hline Expansion of an existing garden & $43 \cdot 1$ & 323 & $37 \cdot 5$ & $281^{*}$ \\
\hline Revitalization of a garden not currently in use & $23 \cdot 0$ & 172 & $22 \cdot 6$ & 169 \\
\hline Nothing; we do not have a school garden & $\mathrm{N} / \mathrm{A}$ & & $2 \cdot 3$ & 20 \\
\hline I do not know & $\mathrm{N} / \mathrm{A}$ & & $1 \cdot 5$ & 13 \\
\hline \multicolumn{5}{|l|}{ When was (will) the garden (be) used for instruction? } \\
\hline Academic class time & $96 \cdot 0$ & 719 & $79 \cdot 2$ & $593^{\star \star \star}$ \\
\hline After-school programme & $59 \cdot 5$ & 446 & $40 \cdot 7$ & $305^{\star * *}$ \\
\hline Before-school programme & $13 \cdot 2$ & 99 & $5 \cdot 1$ & $38^{\star * *}$ \\
\hline Lunch/recess time & $53 \cdot 0$ & 397 & $39 \cdot 7$ & $297^{\star * *}$ \\
\hline \multicolumn{5}{|c|}{ Which subject areas will be taught using the school garden as a learning laboratory? } \\
\hline Agricultural studies & $49 \cdot 5$ & 371 & $45 \cdot 3$ & 339 \\
\hline Art & $52 \cdot 6$ & 394 & $40 \cdot 2$ & $301^{\star * *}$ \\
\hline Environmental science & $76 \cdot 2$ & 571 & $63 \cdot 6$ & $476^{\star \star *}$ \\
\hline Foreign language & $6 \cdot 7$ & 50 & $3 \cdot 7$ & $28^{\star}$ \\
\hline Health & $66 \cdot 4$ & 497 & $50 \cdot 1$ & $375^{\star * *}$ \\
\hline History/social science & $40 \cdot 2$ & 301 & $22 \cdot 8$ & $171^{\star \star *}$ \\
\hline Home economics & $20 \cdot 2$ & 151 & $13 \cdot 4$ & $100^{\star \star *}$ \\
\hline Language arts & $58 \cdot 5$ & 438 & $35 \cdot 1$ & $263^{\star * *}$ \\
\hline Mathematics & $65 \cdot 4$ & 490 & $42 \cdot 3$ & $317^{\star \star *}$ \\
\hline Music & $10 \cdot 2$ & 76 & $4 \cdot 8$ & $36^{\star \star *}$ \\
\hline Nutrition & $82 \cdot 4$ & 617 & $61 \cdot 6$ & $461^{\star \star \star}$ \\
\hline Physical education & $20 \cdot 7$ & 155 & $15 \cdot 1$ & $113^{*}$ \\
\hline Science & 93.5 & 700 & $77 \cdot 6$ & $581^{\star \star *}$ \\
\hline Special education & $42 \cdot 3$ & 317 & $20 \cdot 6$ & $154^{\star * *}$ \\
\hline
\end{tabular}

N/A, not applicable.

Significant differences at ${ }^{\star} P \leq 0.01$ and ${ }^{\star \star \star} P<0.001$ (McNemar's $\chi^{2}$ test).

tData from the Garden Grant Pre-Survey.

‡Data from the Garden Grant Follow-Up Survey. 
Table 2 Utilization and sufficiency of funds

\begin{tabular}{|c|c|c|}
\hline & $\%$ & $n$ \\
\hline \multicolumn{3}{|l|}{$\begin{array}{l}\text { Was your school able to utilize all of the grant funds awarded by the California Instructional School } \\
\text { Garden Program grant? }\end{array}$} \\
\hline Yes. We were able to utilize all of our grant funds on our school garden & $63 \cdot 5$ & 535 \\
\hline No. We received all of our grant funds but were not able to utilize all of the grant funds & $19 \cdot 3$ & 163 \\
\hline No. Some of our funds were not distributed to our school & $5 \cdot 3$ & 45 \\
\hline No. None of our funds were distributed to our school & $3 \cdot 2$ & 27 \\
\hline I do not know & $5 \cdot 7$ & 48 \\
\hline Other & $3 \cdot 0$ & 25 \\
\hline Missing & - & 18 \\
\hline \multicolumn{3}{|l|}{$\begin{array}{l}\text { Were the grant funds received from the California Instructional School Garden Program sufficient to } \\
\text { meet your gardening needs? }\end{array}$} \\
\hline Yes. We were able to accomplish all of our goals for our garden with the funds we received & $39 \cdot 4$ & 322 \\
\hline No. The funds we received were not sufficient to reach our gardening goals & $25 \cdot 9$ & 212 \\
\hline $\begin{array}{l}\text { No. The funds we received were not sufficient to reach our gardening goals, so we acquired other } \\
\text { sources of funding }\end{array}$ & $15 \cdot 6$ & 128 \\
\hline I do not know & $5 \cdot 6$ & 46 \\
\hline Other & $13 \cdot 4$ & 110 \\
\hline Missing & - & 43 \\
\hline
\end{tabular}

Table 3 Impact of California budget crisis

\begin{tabular}{|c|c|c|}
\hline & $\%$ & $n$ \\
\hline \multicolumn{3}{|l|}{ How has the 2008-2009 California budget deficit affected your school garden programme? } \\
\hline The school garden has not been affected by the budget deficit & $50 \cdot 4$ & 426 \\
\hline The school garden has been negatively affected by the budget deficit & $37 \cdot 8$ & 319 \\
\hline The school garden has been positively affected by the budget deficit & $0 \cdot 7$ & 6 \\
\hline I do not know & $11 \cdot 1$ & 94 \\
\hline Missing & - & 16 \\
\hline \multicolumn{3}{|l|}{ In what ways has your school garden been negatively affected by the budget deficit? $\dagger$} \\
\hline Loss of funds for a garden coordinator & $18 \cdot 8$ & 60 \\
\hline Loss of other funds, excluding California Instructional School Garden grant funds & $49 \cdot 8$ & 159 \\
\hline Loss of teacher(s) committed to school gardens & $27 \cdot 0$ & 86 \\
\hline Loss of community volunteers & $18 \cdot 5$ & 59 \\
\hline Other & $42 \cdot 3$ & 135 \\
\hline
\end{tabular}

tIf the respondent marked, 'The school garden has been negatively affected by the budget deficit', they were directed to answer, 'In what ways has your school garden been negatively affected by the budget deficit? Check all that apply'.

Over one-third of schools $(37 \cdot 8 \%)$ reported that the budget crisis negatively affected their school garden. A very small number of schools $(0.7 \%)$ reported that the budget crisis positively affected their school garden (Table 3 ). Of the schools that were negatively affected by the budget crisis, $18 \cdot 8 \%$ lost funds for a garden coordinator, $49 \cdot 8 \%$ lost general funds, $27 \cdot 0 \%$ lost teachers committed to school gardens and $18.5 \%$ lost community volunteers (Table 3 ).

\section{Discussion}

Throughout the USA, gardening is becoming increasingly popular for a multitude of environmental, health and social reasons ${ }^{(18)}$. This is evidenced by the expanding People's Garden Initiative supported by the US Department of Agriculture and the accompanying People's Garden School Pilot Program ${ }^{(18,19)}$. Other organizations provide grants to support child-centred garden programmes; one such programme is the Youth Garden Grants disseminated by The National Gardening Association (NGA) ${ }^{(20)}$. This programme provides \$US 1000 (\$US 500 gift card to the Home Depot and a \$US 500 gift card to the Gardening with Kids catalogue and educational materials from the NGA) to five organizations and a \$US 500 gift card to the Home Depot to ninety-five organizations and provides highlights of their evaluation. This programme is fundamentally different from the CISGP in terms of the funding source: private companies. Utilizing a private funding source allows Youth Garden Grants to ensure that funding exists and that it will be disseminated appropriately to all recipients, something that was not observed for the CISGP.

As gardening programmes at the government, community and school level increase, it is imperative to disseminate evaluations of previous programmes to allow other funders/participants to be as informed as possible to foster success. This evaluation suggests that the CISGP had mixed results in assisting schools in implementing, maintaining and sustaining a school garden programme.

Many factors impact the success of a grant programme. During the time period when schools utilized their grant funds (2007-2008 and 2008-2009) the state of California 
was confronted with a severe budget shortfall. Partial funding was removed from all state programmes, including education. Schools were forced to make drastic changes to their budgets, and many programmes that were perceived to be expendable were removed. The CISGP grant programme was implemented during a time when the California state budget had a surplus of over \$US 9 billion $^{(21)}$. When the applications were processed and money released to the schools, the state budget was in a deficit. In addition, the grant funds were sent to the district offices to be distributed to schools. However, California Senate Bill X3 $4^{(22)}$, passed on 20 February 2009 , allowed district offices to utilize the monies for instructional purposes, regardless of their intended purpose. Some school districts did not disperse all grant funds to their schools and not all schools received all of their funds. In addition, schools reported that the funds that they did receive were not sufficient to achieve their gardening goals.

In addition to the direct impact of the budget deficit on the dissemination of grant funds, many schools reported that their school garden programme had been negatively affected by the budget deficit. It is important to mention that only schools that planned to revitalize a garden not currently in use achieved that goal, and suggests that environmental barriers may exist in schools in which there has never been a school garden and that the funding provided was not enough to overcome those barriers. It is also possible that those schools that planned on revitalizing unused gardens had more realistic expectations. Although it may not be possible to tease out the impact of the budget shortfall or the insufficiency of the grant amount, it is paramount to recognize that the effectiveness of the CIGSP was impacted significantly.

Results from the present study indicate that schools were, in general, not able to accomplish what they had predicted with regard to the utilization of their school gardens. However, many schools were able to implement the creation of new and revitalized school gardens and sustain them for the duration of the evaluation. Many schools did utilize their school gardens for academic instruction, but not as frequently, nor did they teach as many subjects as predicted. Almost $80 \%$ of schools (79.2\%) used their gardens during academic class time, although $96 \%$ predicted that they would. Although not all schools were as successful as they had predicted, the CISGP was successful in increasing the number of gardens used for academic instruction. One possible reason for the lower than expected utilization is that the individual originally in charge of these programmes may have been removed from that position. Only agricultural studies was taught as frequently as predicted. This may be due to the fact that many junior and high schools have agricultural programmes that are part of the standard curriculum and may not have been impacted as much as other academic garden programmes. In summary, the difference between proposed and achieved garden goals may be due to the budget shortfall or insufficiency of the grant award amount, or due to a combination of both.

\section{Acknowledgements}

Funding for this project was partially provided by the California Department of Food and Agriculture Specialty Crops Grant Notice of Funding Availability no. 07-0135 and by the Gustavus and Louise Pfeiffer Research Foundation. The authors have no conflict of interest to declare. E.M. and D.L.B. assisted with the creation of survey tools; E.L.H. assisted with data collection and analysis and with manuscript preparation.

\section{References}

1. Ozer EJ (2007) The effects of school gardens on students and schools: conceptualization and considerations for maximizing healthy development. Health Educ Behav 34, 846-863.

2. Subramaniam MA, 4-H Center for Youth Development (2002) Garden-based learning in basic education: a historical review. http://www.ca4h.org/files/1229.pdf (accessed March 2011).

3. Sherman J \& Muehlhoff E (2007) Developing a nutrition and health education program for primary schools in Zambia. J Nutr Educ Behav 39, 335-342.

4. California School Garden Network (2007) Homepage. http://www.csgn.org/ (accessed November 2009).

5. Somerset S \& Bossard A (2009) Variations in prevalence and conduct of school food gardens in tropical and subtropical regions of north-eastern Australia. Public Health Nutr 12, 1485-1493.

6. California Department of Education (2011) School garden program overview. http://www.cde.ca.gov/Ls/nu/he/ gardenoverview.asp

7. Institute of Medicine (2006) Progress in Preventing Childhood Obesity: How Do We Measure Up? Brief Report. http://www.iom.edu/ /media/Files/Report\%20Files/2006/ Progress-in-Preventing-Childhood-Obesity-How-Do-WeMeasure-Up/11722_reportbrief.ashx (accessed June 2010).

8. Birch LL \& Fisher JO (1998) Development of eating behaviors among children and adolescents. Pediatrics 101, 539-549.

9. Morris JL \& Zidenberg-Cherr S (2002) Garden-enhanced nutrition curriculum improves fourth-grade school children's knowledge of nutrition and preferences for some vegetables. J Am Diet Assoc 102, 91-93.

10. McAleese JD \& Rankin LL (2007) Garden-based nutrition education affects fruit and vegetable consumption in sixthgrade adolescents. J Am Diet Assoc 107, 662-665.

11. Heim S, Stang J \& Ireland M (2009) A garden pilot project enhances fruit and vegetable consumption among children. J Am Diet Assoc 109, 1220-1226.

12. Hermann JR, Parker SP, Brown BJ et al. (2006) After-school gardening improves children's reported vegetable intake and physical activity. J Nutr Educ Behav 38, 201-202.

13. Parmer SM, Salisbury-Glennon J, Shannon D et al. (2009) School gardens: an experiential learning approach for a nutrition education program to increase fruit and vegetable knowledge, preference, and consumption among second-grade students. J Nutr Educ Behav 41, 212-217. 
14. Murphy JM (2003) Findings from the Evaluation Study of the Edible Schoolyard. Berkeley, CA: Center for Ecoliteracy.

15. Graham H, Beall DL, Lussier M et al. (2005) Use of school gardens in academic instruction. J Nutr Educ Behav 37, 147-151.

16. UC Davis Center for Nutrition in Schools (2010) Homepage. http://cns.ucdavis.edu/ (accessed December 2010).

17. Schaefer D \& Dillman D (1998) Development of a standard e-mail methodology: results of an experiment. Public Opin $Q$ 62, 378-397.

18. US Department of Agriculture (2009) People's Garden Initiative. http://www.usda.gov/wps/portal/usda/usdahome? navid=PEOPLES_GARDEN (accessed March 2011).
19. US Department of Agriculture (2010) People's Garden School Pilot Program. http://www.fns.usda.gov/fns/outreach/grants/ garden.htm (accessed March 2011).

20. The National Gardening Association (2011) Youth Garden Grants. http://www.kidsgardening.org/ (accessed March 2011).

21. California Department of Finance (2011) Historical Data, General Fund Budget Summary: Chart A. http://www.dof. ca.gov/budgeting/budget_faqs/information/documents/ Chart-A.pdf (accessed September 2009).

22. Senate Bill X3 4 (2009) http://www.leginfo.ca.gov/pub/ 09-10/bill/sen/sb_0001-0050/sbx3_4_bill_20090220_chaptered. pdf (accessed October 2009). 